\title{
Pengendalian Jumlah Persediaan Bahan Baku Kerudung Pada RAR Azkia Padalarang
}

\author{
Inventory Control of Hijab Raw Materials at RAR Azkia Padalarang \\ Farid H Badruzzaman, Erwin Harahap \\ Program Studi Matematika, FMIPA, Universitas Islam Bandung \\ faridhb@unisba.ac.id,erwin2h@unisba.ac.id
}

\begin{abstract}
Abstrak. Penelitian dilakukan di RAR Azkia Padalarang Bandung Barat dengan tujuan untuk mengetahui kuantitas optimal bahan baku dalam setiap kali pembelian/pemesanan $(E O Q)$. Data dikumpulkan dengan metode wawancara, dianalisis dengan teknik analisis deskriptif dengan pendekatan kuantitatif. Jumlah pemesanan dalam satu tahun (2015) adalah sebanyak $115.000 \mathrm{Kg}$ dengan rata-rata per bulan adalah 9583,33 kg dibulatkan $9583 \mathrm{~kg}$. Hasil penelitian menunjukkan bahwa jumlah optimal pemesanan atau pembelian bahan baku untuk satu kali pesan adalah $8522,579 \mathrm{~kg}$ dibulatkan $8523 \mathrm{~kg}$. Frekuensi pembeliannya adalah $14 \mathrm{kali}$, daur pemesanannya adalah 26-27 hari, dan terdapat selisih jumlah pemesanan $1060 \mathrm{~kg}$ per tahun.
\end{abstract}

Kata kunci: economic order quantity, rar azkia, pembelian, pemesanan

\begin{abstract}
The study was conducted at RAR Azkia Padalarang, West Bandung with the aim to determine the optimal quantity of raw materials in each purchase/order (EOQ). Data were collected by interview method, analyzed by descriptive analysis techniques with quantitative approaches. The number of orders in one year (2015) is $115,000 \mathrm{~kg}$ with an average per month of $9583.33 \mathrm{~kg}$ rounded $9583 \mathrm{~kg}$. The results showed that the optimal number of orders or purchases of raw materials for one order was $8522,579 \mathrm{~kg}$ rounded $8523 \mathrm{~kg}$. The frequency of purchases is 14 times, the order cycle is 26-27 days, and there is a difference in the number of orders of $1060 \mathrm{~kg}$ per year.
\end{abstract}

Keywords: economic order quantity, rar azkia, purchase, order

\section{Pendahuluan}

Sebuah perusahaan didirikan pada umumnya, bertujuan untuk memperoleh keuntungan dan menjaga keberlangsungan usahanya. Untuk mencapai tujuan tersebut tidaklah mudah, hal ini karena dipengaruhi oleh berbagai faktor. Salah satu faktor penting yang mempengaruhi pencapaian tujuan, adalah kelancaran dalam proses produksi. Proses produksi merupakan bagian kegiatan untuk menambah nilai suatu barang dengan memanfaatkan sumber daya, baik bahan baku, sumber daya manusia dan peralatan produksi. Melalui proses produksi, perusahaan mengolah bahan baku, menjadi produk yang dapat dijual kepada masyarakat, guna mendapatkan keuntungan.

Persediaan merupakan faktor utama di dalam sebuah perusahaan. Persediaan didefinisikan sebagai barang yang disimpan untuk digunakan pada periode mendatang. Persediaan dalam suatu unit usaha dapat dikategorikan sebagai modal kerja yang berbentuk barang. Jumlah persediaan yang tidak tepat dapat merugikan perusahaan. Persediaan yang terlalu banyak dapat meningkatkan biaya penyimpanan. Sebaliknya, jika persediaan terlalu sedikit, maka dapat meningkatkan biaya kekurangan persediaan.

Perusahaan memproduksi barang umumnya menurut jumlah pesanan konsumen. Bagian produksi harus memperhitungkan mengenai tingkat persediaan yang ada serta perkiraan penjualan produk. Apabila terdapat kesalahan dalam menentukan jumlah bahan baku, maka akan dapat mengakibatkan kekurangan, sehingga menimbulkan kerugian. Dan apabila kelebihan jumlah produksi akan menimbulkan persediaan jumlah produksi yang menumpuk. Adanya penumpukan persediaan jumlah produksi akan menimbulkan biaya persediaan serta kemungkinan terjadinya keusangan dan kualitas yang tidak bisa dipertahankan, sehingga akan dapat mengurangi laba perusahaan. Sebaliknya 
kekurangan jumlah produksi akan mengakibatkan kemacetan dalam proses penjualan, sehingga keuntungan yang diperoleh perusahaan akan berkurang. Oleh karena itu perusahaan perlu menghitung jumlah produksi dengan baik, sehingga memiliki persediaan bahan baku yang optimal [1].

\section{Materi dan Metode}

Fungsi persediaan dapat diuraikan sebagai berikut [2]:

\section{Fungsi Decoupling}

Fungsi penting persediaan adalah memungkinkan operasi-operasi perusahaan internal dan eksternal mempunyai kebebasan. Persediaan decoupling ini memungkinkan perusahaan dapat memenuhi permintaan langganan tanpa tergantung pada supplier.

2. Fungsi Economic Lot Sizing

Persediaan lot size ini perlu mempertimbangkan penghematan- penghematan, karena perusahaan melakukan pembelian dalam kuantitas yang lebih besar dibandingkan dengan biaya-biaya yang timbul karena besarnya persediaan.

3. Fungsi Antisipasi

Perusahaan sering menghadapi fluktuasi permintaan yang dapat diperkirakan atau diramalkan berdasarkan pengalaman atau data masa lalu. Di samping itu, perusahaan juga sering menghadapi ketidakpastian jangka waktu pengiriman dan permintaan akan bahan baku selama periode pemesanan kembali, sehingga memerlukan kuantitas persediaan ekstra yang sering disebut persediaan pengaman (safety inventories).

Bahan baku adalah barang yang dibuat menjadi barang lain [3]. Sedangkan tingkat penggunaan bahan baku adalah seberapa banyak jumlah bahan baku yang dipergunakan dalam proses produksi [46]. Dalam penelitian ini, kebutuhan bahan baku kain bulan Januari sampai Desember tahun 2016 RAR Azkia belum diketahui. Oleh karena itu, dilakukan peramalan kebutuhan bahan baku, dengan menggunakan metode Trend Projection. Teknik ini menyesuaikan dengan garis trend suatu rangkaian titik-titik data historis suatu perusahaan dan kemudian diproyeksikan dengan ramalan periode yang akan datang.

Perumusan EOQ yaitu mencari biaya total keseluruhan di mana parameternya yaitu jumlah dari biaya simpan, biaya pesan dan biaya beli. Biaya pembelian merupakan perkalian antara jumlah barang dan harga per unitnya. Biaya pesan merupakan perkalian antara frekuensi pemesanan dan biaya pesan. Hal-hal yang perlu diperhatikan dalam penggunaan bahan baku, antara lain :

1. Jumlah perkiraan bahan baku yang akan dipergunakan di dalam proses produksi pada suatu periode yang akan datang.

2. Harga dari bahan baku yang akan dibeli menjadi salah satu faktor penentu dalam kebijaksanaan persediaan bahan, guna penyusunan perhitungan berapa besar dana perusahaan yang harus disediakan untuk investasi dalam persediaan bahan baku tersebut.

3. Biaya-biaya persediaan.

a. Biaya penyimpanan (holding cost/ carrying cost)

b. Biaya pemesanan atau pembelian (ordering cost)

4. Pemakaian bahan baku pada periode-periode yang lalu merupakan salah satu faktor yang perlu diperhatikan karena untuk keperluan proses produksi akan dipergunakan sebagai salah satu dasar pertimbangan dalam pengadaan bahan baku pada periode berikutnya.

5. Waktu tunggu adalah tenggang waktu yang diperlukan antara saat pemesanan bahan baku dengan da datangnya bahan baku itu sendiri.

6. Persediaan pengaman merupakan suatu persediaan yang dicadangkan sebagai pengaman dari kelangsungan proses produksi perusahaan. Persediaan pengaman diperlukan karena dalam kenyataannya jumlah bahan baku yang diperlukan untuk proses produksi tidak selalu tepat seperti yang direncanakan. 
7. Pemesanan kembali adalah saat perusahaan harus mengadakan pemesanan bahan dasar kembali, sehingga datangnya pesanan tersebut tepat dengan habisnya bahan dasar yang dibeli.

\section{Hasil Pembahasan}

Berikut disajikan Tabel 1 jumlah pembelian bahan baku kain setiap pemesanan

Tabel 1. Jumlah Pembelian Tahun 2015

\begin{tabular}{|c|l|c|}
\hline No & \multicolumn{1}{|c|}{ Bulan } & Jumlah Bahan Baku (dalam kg) \\
\hline 1 & Januari & 8450 \\
\hline 2 & Februari & 8200 \\
\hline 3 & Maret & 9500 \\
\hline 4 & April & 9800 \\
\hline 5 & Mei & 10050 \\
\hline 6 & Juni & 10300 \\
\hline 7 & Juli & 10200 \\
\hline 8 & Agustus & 10050 \\
\hline 9 & September & 10000 \\
\hline 10 & Oktober & 9800 \\
\hline 11 & Nopember & 9400 \\
\hline 12 & Desember & 9250 \\
\hline & Jumlah & $\mathbf{1 1 5 0 0 0}$ \\
\hline
\end{tabular}

Sebagaimana ditunjukkan pada Tabel 2, Jumlah permintaan dalam satu tahun adalah kurang lebih sebanyak $115000 \mathrm{~kg}$ dengan rata-rata perbulan adalah 9583,33 kg.

Tabel 2. Jumlah Penggunaan Bahan Baku

\begin{tabular}{|c|l|c|c|}
\hline No & Bulan & $\begin{array}{c}\text { Jumlah Penggunaan Bahan } \\
\text { Baku (kg) }\end{array}$ & Kurang / Lebih * \\
\hline 1 & Januari & 8.290 & 160 \\
\hline 2 & Februari & 8.185 & 175 \\
\hline 3 & Maret & 9.800 & -125 \\
\hline 4 & April & 9.925 & -125 \\
\hline 5 & Mei & 9.900 & 150 \\
\hline 6 & Juni & 10.300 & 150 \\
\hline 7 & Juli & 10.190 & 160 \\
\hline 8 & Agustus & 10.230 & -20 \\
\hline 9 & September & 9.990 & 10 \\
\hline 10 & Oktober & 9.890 & -80 \\
\hline 11 & Nopember & 9.570 & -210 \\
\hline 12 & Desember & 9.460 & $\mathbf{7 5}$ \\
\hline \multicolumn{2}{|l|}{ Jumlah } & $\mathbf{1 1 5 . 7 3 0}$ & \\
\hline
\end{tabular}

*) Tanda positif berarti kelebihan dan tanda negative berarti kekurangan 
Tabel 3. Biaya Persiapan Pemesanan

\begin{tabular}{|l|l|}
\hline \multicolumn{1}{|c|}{ Uraian } & \multicolumn{1}{c|}{ Tahun 2015 } \\
\hline Kuantitas & $115.730 \mathrm{~kg}$ \\
\hline Harga & Rp. $45.000 / \mathrm{kg}$ \\
\hline Biaya total & Rp. 5.207 .850 .000 \\
\hline Biaya Pemesanan & Rp. 4.393 .333 \\
\hline Biaya Penyimpanan & Rp. 14.000 \\
\hline
\end{tabular}

Biaya persiapan pemesanan selama tahun 2015 sebagaimana ditunjukkan pada Tabel 3 adalah Rp. 15.250.000,- biaya sarana komunikasi dan administrasi adalah Rp. 27.770.000, dan biaya pengiriman adalah Rp. 9.700.000. Total semua biaya pemesanan adalah Rp. 52.720.000, dan rata-rata biaya per bulannya adalah Rp. 4.393.333. Untuk biaya penyimpanan ditetapkan sebesar Rp. 14.000. Perhitungan EOQ dan Penentuan Kuantitas Pembelian Bahan Baku Optimal dilakukan melalui kalkulasi sebagai berikut:

$$
E O Q=\sqrt{\frac{2 S D}{H}}
$$

$E O Q=$ Kuantitas pembelian optimal

$\mathrm{S} \quad=$ Biaya pemesanan setiap kali pesan

$\mathrm{D} \quad=$ Penggunaan bahan baku per tahun

$\mathrm{H} \quad$ = Biaya penyimpanan per unit

$$
\begin{gathered}
E O Q=\sqrt{\frac{2(4393333)(115730)}{14000}} \\
E O Q=8522,579
\end{gathered}
$$

Jadi, jumlah pembelian untuk satu kali pesan adalah 8522,579 dibulatkan $8523 \mathrm{~kg}$.

Frekuensi pembeliannya adalah $=\frac{115730}{8522,579}=13,579 \equiv 14 \mathrm{kali}$

Daur pemesanannya adalah $=\frac{360}{13,579}=26,512$ hari

\section{Kesimpulan}

Pengendalian bahan baku penting bagi setiap usaha bisnis. Tujuan pengendalian bahan baku adalah untuk mengetahui kuantitas optimal dalam setiap kali pembelian bahan baku (EOQ). Data pemesanan bahan baku dalam satu tahun (2015) adalah sebanyak $115000 \mathrm{~kg}$ dengan rata-rata perbulan adalah $9583,33 \mathrm{~kg}$ dibulatkan $9583 \mathrm{~kg}$. Hasil penelitian menunjukkan bahwa jumlah optimal pemesanan atau pembelian bahan baku untuk satu kali pesan adalah $8522,579 \mathrm{~kg}$ dibulatkan $8523 \mathrm{~kg}$. Frekuensi pembeliannya adalah 14 kali. Daur pemesanannya adalah 26-27 hari. Ada selisih jumlah pemesanan $1060 \mathrm{~kg}$ per-tahun. 


\section{Referensi}

[1] Taha, Hamdy A Taha, “Operations Research. Seventh Edition”, Pearson Education International Inc. Prentice Hall, 2003.

[2] Rangkuti, Freddy. (2004). Manajemen Persediaan. Jakarta: Raja Grafindo Persada

[3] Kamus Besar Bahasa Indonesia Online. Diakses: Februari 2018. https://kbbi.kata.web.id/bahan-baku/

[4] FH Badruzzaman, E Harahap, E Kurniati, MD Johansyah, "Pengendalian Persediaan Produksi Hijab Berdasarkan Economic Production Quantity di RAR Azkia”, Jurnal Matematika Vol 16 No 2, 2017.

[5] MY Fajar, E Harahap, FH Badruzzaman, "Penentuan EOQ Masalah Persediaan Multi-Item Dengan NonLinear Goal Programming”, Jurnal Matematika Vol 6 No 1, 2007.

[6] RM Hidayat, RD Muchlis, FH Badruzzaman, "Model EOQ untuk Permintaan Bergantung Waktu Dengan Mempertimbangkan Laju Kerusakan”, Jurnal Matematika Vol 15 No 1, 2016. 
(Halaman ini sengaja dikosongkan) 